\title{
ASSESSMENT OF THE MAXIMUM POSSIBLE EXTENSION OF BUCKET WHEEL SchRs740 BOOM BASED ON STATIC AND DYNAMIC CALCULATION
}

\author{
Branko Petrović, Ana Petrović, Dragan Ignjatović, Ines Grozdanović, Dražan Kozak, Marko Katinić
}

Professional paper

Bucket wheel boom represents the most loaded and the most responsible part of the excavator structure, participating only with 6 to $13 \%$ in the entire excavator weight. Its length is selected depending on the technological requirements of mining deposit, and it has to be adjusted with the designed possibilities of the excavator. At the request of mining technology that is in compliance with the soil-mechanical properties of deposit, conditions for the selection of excavator optimal parameters are created, and therefore for determining the required length of the boom. In this paper, analysis of dynamic and static behaviour of boom extended from 1 to $10 \mathrm{~m}$ with a step $1 \mathrm{~m}$ was done. The maximum possible extension is defined as the aspect of the structural performance, dynamic behaviour and stress field. Finite Element Method (FEM) is used to obtain natural frequencies, displacements and stresses.

Keywords: bucket wheel boom; dynamics; FEM; increasing the boom length; stress

Procjena maksimalnog mogućeg produljenja strijele bagera SchRs740 na osnovi statičkog i dinamičkog proračuna

Stručni članak

Strijela predstavlja najopterećeniji i najodgovorniji dio konstrukcije rotornog bagera, sudjelujući sa samo 6 do $13 \%$ u ukupnoj težini bagera. Njena duljina se bira u ovisnosti od tehnoloških zahtjeva kopanja, a mora biti usklađena s projektnim mogućnostima bagera. Na zahtjev rudarske tehnologije koja je u skladu s mehaničkim svojstvima depozita, stvaraju se uvjeti za izbor optimalnih parametara bagera, a samim tim za određivanje potrebne duljine strijele. U ovom radu urađena je analiza dinamičkog ponašanja strijele produljene od 1 do $10 \mathrm{~m} \mathrm{~s}$ korakom od $1 \mathrm{~m}$. Maksimalno moguće produljenje definirano je sa stajališta strukturalne izvedbe, dinamičkog ponašanja i polja naprezanja. Numerička metoda konačnih elemenata korištena je da se dobiju vlastite frekvencije titranja, pomaci i naprezanja.

Ključne riječi: dinamika; metoda konačnih elemenata; naprezanje; povećanje duljine strijele; strijela rotornog bagera

\section{Introduction}

One of the basic prerequisites for the efficient operation of the excavator is the adjustment of structures, primarily the bucket wheel boom of the excavator, and working conditions. It involves the use of such structures that will best suit the specific conditions of the working environment, but also that structural loadings are within acceptable limits, in order to stay long in exploitation. Bucket wheel boom is most exposed to a wide range of both static and dynamic loads. The object of observation in this paper is bucket wheel excavator SchRs740 boom structure. Bucket wheel excavator SchRs740 (Fig. 1) is operating at Tamnava West Field, Mining Basin Kolubara.

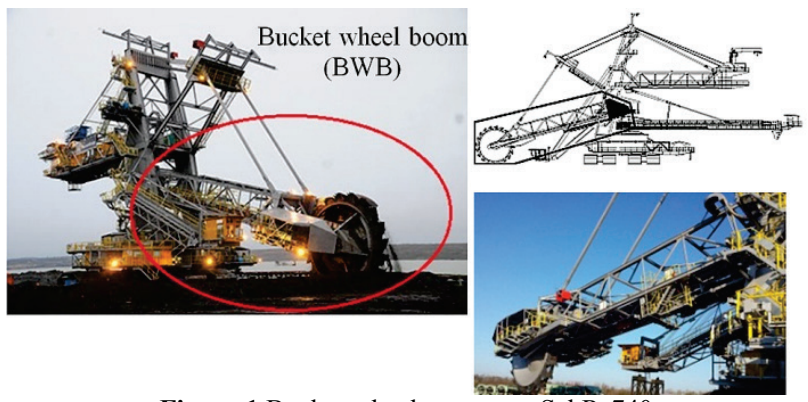

Figure 1 Bucket wheel excavator SchRs740

In order to determine the behaviour of the bucket wheel excavator SchRs740 boom structure, firstly the static and dynamic loads are analysed. Then, development of the model was performed and ultimately finite element analysis. FEM will determine the level of membrane, bending and equivalent stresses and deformations as well as values of free frequencies of the structure. Based on theoretical considerations on the one hand, as well as relevant diagnostic indicators of certain design solutions on the other hand (concentration of stresses, deformation energy, distribution of potential and kinetic energy on the main oscillating modes), can be marked weak points and found design solutions depending on technological requirements that best suit the specific conditions of the working environment on opencast mines. In this case technological requirement is increasing the bucket wheel boom length of the excavator SchRs740.

Modelling and simulation of the dynamic behaviour of an elevator are shown in [1]. Analysis of the dynamic behaviour and condition of the BWE elements using the finite element method, are shown in many papers [2-7]. In some papers $[3 \div 6]$ experimental results are compared with appropriate theoretical basis.

Modelling of the BWE SchRs740 bucket wheel boom in this paper was carried out because of the technological requirement to increase the length of the boom. In [8] comparative analysis of the bucket wheel boom length influence on the technical parameters of the block, as well as on the capacity of different types of the excavators is shown.

\section{FEM model of the BWE SchRs740 Bucket Wheel Boom}

The basic procedure in diagnostics of the structure is its computer modelling and the corresponding static, dynamic and thermal calculation using the numerical method FEM. FEM is a universal method that can help in solving various problems related both to the behaviour of steel structures and in mining and metallurgical industry $[9,10]$.

The software package KOMIPS is developed at the Faculty of Mechanical Engineering in Belgrade [11], 
which enables modelling and calculation of complex structures and problems.

The most sensitive, the most important and most difficult manageable procedure of the calculation process is structure modelling. One of the most important factors in modelling represents experience and user's intuition. Modelling, in fact, is mapping the physical to computational model according to technical documentation, selection of the type or types of finite elements and defining of physical model discretization by finite elements, nodal points, boundary conditions and loads.

For modelling of the excavator SchRs740 boom, the previously mentioned software package KOMIPS is used. Taking into account the appearance of the excavator SchRs 740 boom structure, and all the above mentioned in relation to the finite element method, the structure was modelled by short beam elements, which means that the shear stress due to bending is taken into account. Classical beam theory is applied.

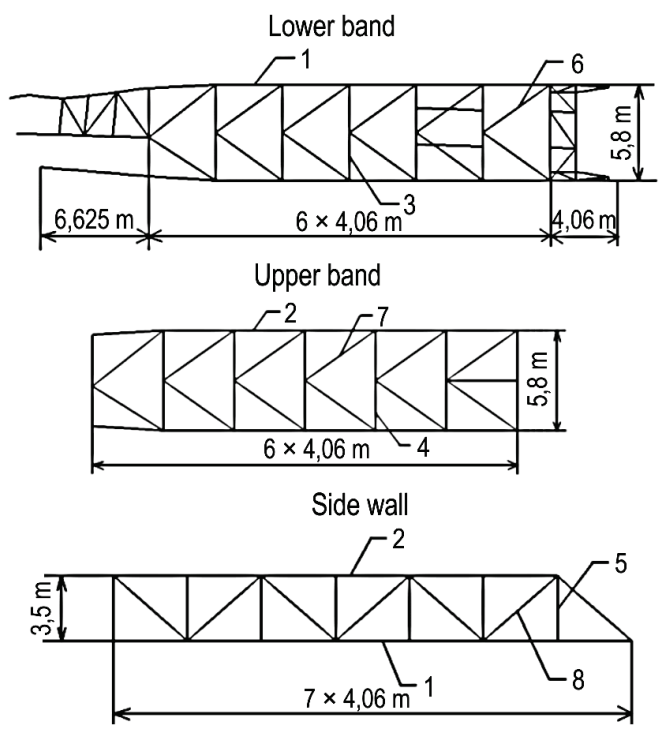

Figure 2 Model of the boom, steel structure
Truss steel structure is shown in Fig. 2. The structure is made of steel $\mathrm{S} 355 \mathrm{~J} 2 \mathrm{G} 3$. The values used in calculations are: modulus of elasticity $210 \mathrm{GPa}$, density $7800 \mathrm{~kg} / \mathrm{m}^{3}$. Other important material property is yield stress, and for this material its value is $350 \mathrm{MPa}$.

A typical element of longitudinal beam (marked as no. 1 in Fig.2) with the corresponding axes is shown in Fig. 3.
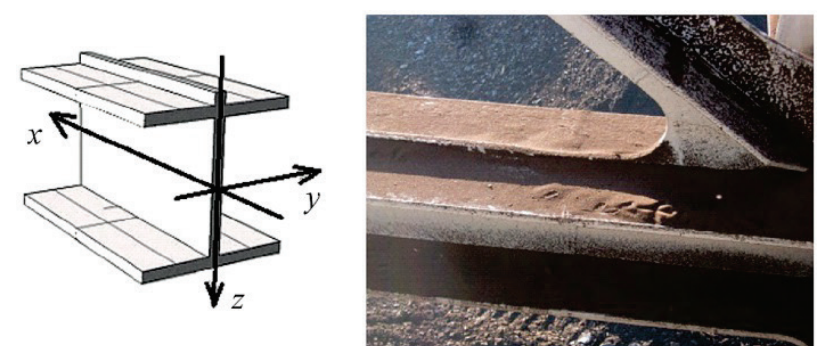

Figure 3 A typical element of longitudinal beam, cross-section

As can be seen from Fig. 2 the axis $\mathrm{x}$ is longitudinal axis, and $y$ and $z$ are principal axes of the cross-section.

Geometrical characteristics of cross-section important for numerical calculations are:

$A_{x}$ - cross-sectional area,

$A_{y}, A_{z}-$ shear areas,

$I_{x}, I_{y}, I_{z}$ - moment of inertia of the axis $x, y$ and $z$,

$W_{x}, W_{y}, W_{z}$ - resistance moment of inertia.

Geometrical characteristics of beam elements of each functional sub-groups of which the boom is made up are shown in Tab. 1. For instance, element highlighted in the table as "longitudinal beam" is a representative of its class. All four longitudinal beams have variable crosssection and all of these changes are taken into account in the calculation.

Elements marked in Fig. 2 and Fig. 4 are matched with their (corresponding) geometrical characteristic shown in Tab. 1.

The geometric properties of cross sections are given in respect to the local coordinate system of beams and orientation relative to the global axes is subsequently defined.

Table 1 The geometrical characteristics of beam elements of each functional sub-group

\begin{tabular}{|c|c|c|c|c|c|c|c|c|c|c|}
\hline & & $A_{x}\left(\mathrm{~cm}^{2}\right)$ & $A_{y}\left(\mathrm{~cm}^{2}\right)$ & $A_{z}\left(\mathrm{~cm}^{2}\right)$ & $I_{x}\left(\mathrm{~cm}^{4}\right)$ & $I_{y}\left(\mathrm{~cm}^{4}\right)$ & $I_{z}\left(\mathrm{~cm}^{4}\right)$ & $W_{x}\left(\mathrm{~cm}^{3}\right)$ & $W_{y}\left(\mathrm{~cm}^{3}\right)$ & $W_{z}\left(\mathrm{~cm}^{3}\right)$ \\
\hline \multirow[t]{2}{*}{ Longitudinal beams } & 1. Lower band (Fig. 2) & 192 & 130 & 58 & 256 & 36710 & 11360 & 128 & 2225 & 701 \\
\hline & 2. Upper band (Fig. 2) & 91 & 64 & 27 & 64 & 13180 & 2136 & 40 & 819 & 214 \\
\hline \multirow[t]{3}{*}{ Transversal beams } & 3. Lower band (Fig. 2) & 63 & 40 & 23 & 18 & 10630 & 1335 & 18 & 686 & 134 \\
\hline & 4. Upper band (Fig. 2) & 44 & 29 & 15 & 8 & 5575 & 778 & 10 & 419 & 86 \\
\hline & 5. Side walls (Fig. 2) & 29 & 16 & 13 & 8 & 329 & 342 & 8 & 39 & 43 \\
\hline \multirow[t]{3}{*}{ Diagonal beams } & 6. Lower band (Fig. 2) & 63 & 23 & 40 & 18 & 1335 & 10630 & 18 & 134 & 686 \\
\hline & 7. Upper band (Fig. 2) & 38 & 34 & 34 & 2169 & 1084 & 1084 & 273 & 136 & 136 \\
\hline & 8. Side walls (Fig. 2) & 50 & 25 & 25 & 24 & 1068 & 956 & 20 & 97 & 90 \\
\hline \multicolumn{2}{|c|}{ 9. Shaft of the wheel (Fig. 4) } & 1799 & 1619 & 1619 & 796436 & 398218 & 398219 & 29498 & 14749 & 14749 \\
\hline
\end{tabular}

Beside the truss steel structure of the boom, all the other elements that affect the rigidity of the boom structure were taken into account. That means that the model includes the following elements: transverse stiffeners, shafts of the wheel and return drum, torque leverage of both gearboxes, parts of the belt structure and stays. Finally, the boom model consists of 290 beam elements and is shown in Fig. 4.

\section{Calculation of the free frequencies of the BWE SchRs740 Bucket Wheel Boom oscillations}

The excavator boom for which dynamic analysis is made is shown in Fig. 5.

Boom is located in an elastic environment, which means the model included the stays and the yoke.

In points that are bearings of the boom translation in all three directions is prevented. In points of connection stays and yoke all the moves (translations and rotations) 
are prevented. In points that represent attachments of the boom and the stays the rotation in the joint around the axis parallel to the bearing axis is allowed. Masses of the gearboxes (by around $8000 \mathrm{~kg}$ ) and the wheel (about $20000 \mathrm{~kg}$ ) are taken into account as a concentrated mass in dynamic calculations, as can be seen (Fig. 5).

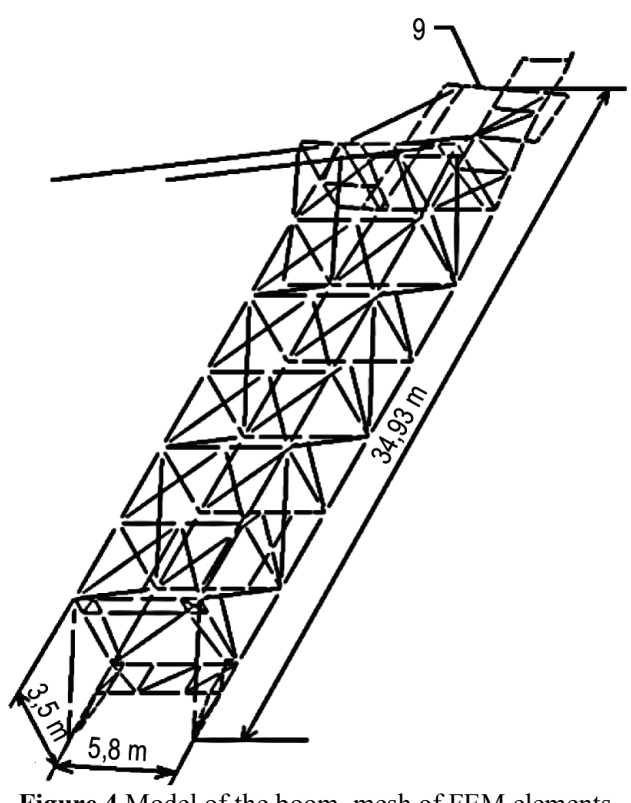

Figure 4 Model of the boom, mesh of FEM elements

\section{Extension of the Bucket Wheel Boom}

Boom has been extended in a step of $1 \mathrm{~m}$, without changing the cross-sections of beams, height and width of the truss. Beam was extended from 1 to $5 \mathrm{~m}$, so that the extension was uniformly distributed on five segments in the middle, which are almost structurally identical (there are small differences, i.e. reinforcement in the lower band of the first and in the upper band of the last segment). Those five segments are marked in Fig. 5. Total extension of $6 \mathrm{~m}$ distributed to these five segments means extending of one segment by $29,56 \%$ of the length. That is negative in many aspects of the structure stiffness. For this reason, the total extension of the boom for $6 \mathrm{~m}$ involves a new segment and the entire extension now is distributed to six $(5+1)$ segments. Numerically it is checked that by the addition of this segment are retained the dynamic characteristics of the structure, regardless of the mass increase (about 1 ton). That confirms that such conceptual solution for extension from $6 \mathrm{~m}$ has grater stiffness compared to a solution where the extension of $6 \mathrm{~m}$ is distributed to five segments. That is why further extensions are done by retaining the inserted segment, and the total length is now distributed to six segments. These extensions of the boom are schematically shown in Fig. 7. During this calculation the original stays of the existing boom were used for each additional extended boom. In addition, stays position was dictated by the geometry (length) of the yoke and stays, which means that it is not the same for the original and the extended booms (Fig. 7).

The actual length of the basic boom is $34,93 \mathrm{~m}$ (hereinafter referred to as about $35 \mathrm{~m}$ long), and its weight is $64869 \mathrm{~kg}$.

The first three oscillating modes and corresponding free frequencies are shown in Fig. 6.

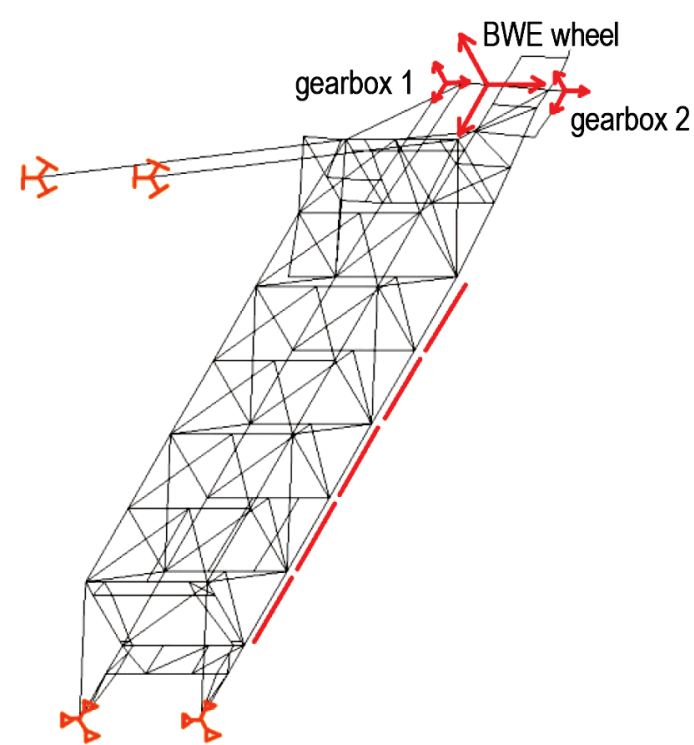

Figure 5 Dynamic model of excavator boom, boundary conditions and loads

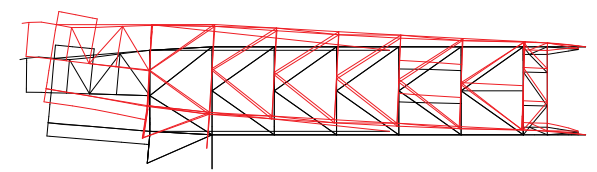

Bending in the horizontal plane, the first mode, $1,44 \mathrm{~Hz}$

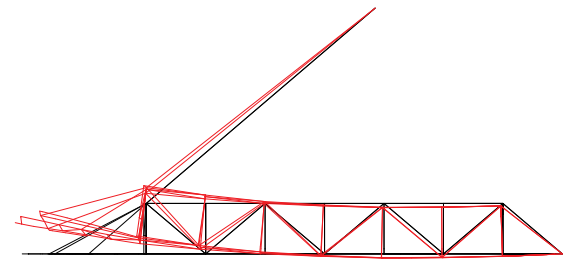

Bending in the vertical plane, the second mode, $3,98 \mathrm{~Hz}$

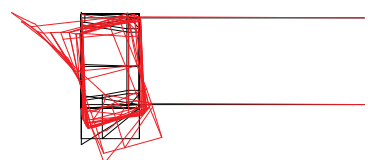

Torsion, the third mode, $5,47 \mathrm{~Hz}$

Figure 6 First three oscillating modes, the original boom structure
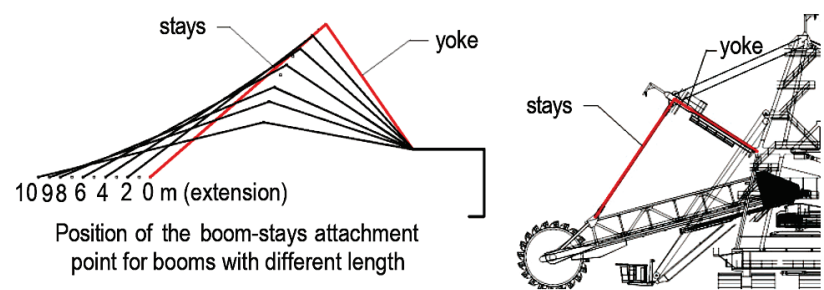

Figure 7 The geometry change of the yoke-stays by the boom extension

Therefore, with the extension of the boom the position of stays is changed, i.e. the angle made by the boom structure and stays is smaller. In addition, $10 \mathrm{~m}$ represents the end border up to which existing stays and yoke can be used, because for each subsequent extension the two circles representing the yoke and stays would not intersect at all.

However, from Fig. 8 can be seen that at extension of $10 \mathrm{~m}$ geometry of yoke-stays is disrupted (the angle between the stays and boom is very small, and between the yoke and stays is very large). 
These variations necessarily require a change in the geometry of the mechanism for the lifting/lowering of the bucket wheel boom, which implies the necessity of elements redesigning (pulleys, ropes, rope drums, drive).

In addition, for the extension of $10 \mathrm{~m}$ the total weight of the boom was increased by about $7600 \mathrm{~kg}$, which would have consequences on the supporting structure of the whole excavator. However, this is not the subject of this paper; consideration here is limited only to the bucket wheel boom structure.

Change in weight by the boom extension and results of dynamic calculation (values of free frequencies) for the original and boom extended from 1 to (fictional) $10 \mathrm{~m}$ are presented in Tab. 2 and Fig. 8.

Table 2 Results of dynamic calculation

\begin{tabular}{|c|c|c|c|c|}
\hline \multirow{2}{*}{$\begin{array}{c}\text { Boom length }(\mathrm{m}) \\
+ \text { Boom extension } \\
(\mathrm{m})\end{array}$} & $\begin{array}{c}\text { Total boom weight } \\
(\mathrm{kg})\end{array}$ & $\begin{array}{c}\text { Bending in the horizontal } \\
\text { plane, the first oscillating } \\
\text { mode }\end{array}$ & $\begin{array}{c}\text { Bending in the vertical } \\
\text { plane, the second oscillating } \\
\text { mode }\end{array}$ & $\begin{array}{c}\text { Torsion, the third oscillating } \\
\text { mode }\end{array}$ \\
\hline $35+0$ & 64869 & 1,44 & 3,98 \\
\hline $35+1$ & 65532 & 1,39 & 3,89 \\
\hline $35+2$ & 66198 & 1,34 & 3,80 \\
\hline $35+3$ & 66867 & 1,29 & 3,69 \\
\hline $35+4$ & 67538 & 1,26 & 3,56 \\
\hline $35+5$ & 68211 & 1,22 & 3,41 \\
\hline $35+6$ & 69862 & 1,19 & 3,29 \\
\hline $35+7$ & 70526 & 1,16 & 3,16 \\
\hline $35+8$ & 71191 & 1,13 & 3,99 \\
\hline $35+9$ & 71855 & 1,11 & 3,79 \\
\hline $35+10$ & 72524 & 1,07 & 3,60 \\
\hline
\end{tabular}

Change in mass by the boom extension

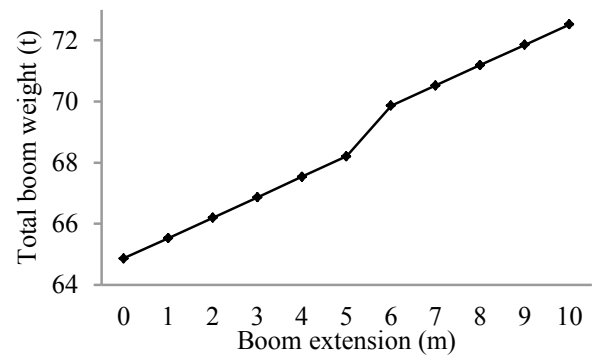

Dynamic calculation for the original and the

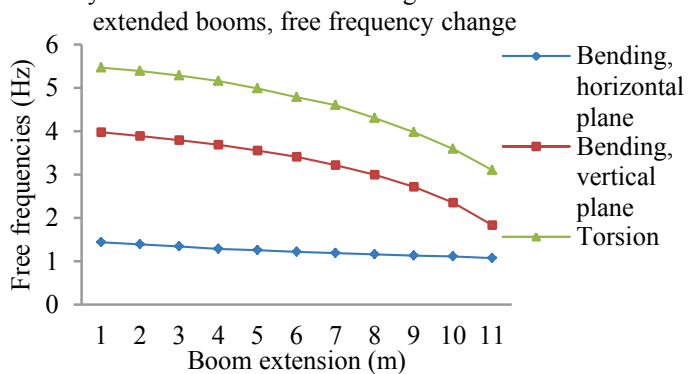

Figure 8 Change in mass by the boom extension and results of dynamic calculation for the original and boom extended from 1 to $10 \mathrm{~m}$

\section{Stress and deformation field in the BWE SchRs740 boom under the workload}

Numerical calculation of structure loaded by the reference workload (static analysis) and its own beams weight (dead load) is done. The boundary conditions are the same as for the dynamic calculation because they represent how the boom is physically attached to the rest of the BWE structure. As workload is concerned, the overall digging force of $250000 \mathrm{~N}$ was distributed in real terms in the three forces (vertical 1, lateral 0.3 and radial 0,15$)$. Also weight of the wheel $(200000 \mathrm{~N})$ and both gearboxes (by $80000 \mathrm{~N}$ ) are taken into calculation. The aim of this analysis was to show the trend of changes in the stress and deflection by increasing the boom length. Load is entered on the bucket wheel perimeter (concentrated force at one point), simulated by rigid beam. Weight of the wheel and gearboxes is applied in relevant points. Fig. 9 represents static load case.

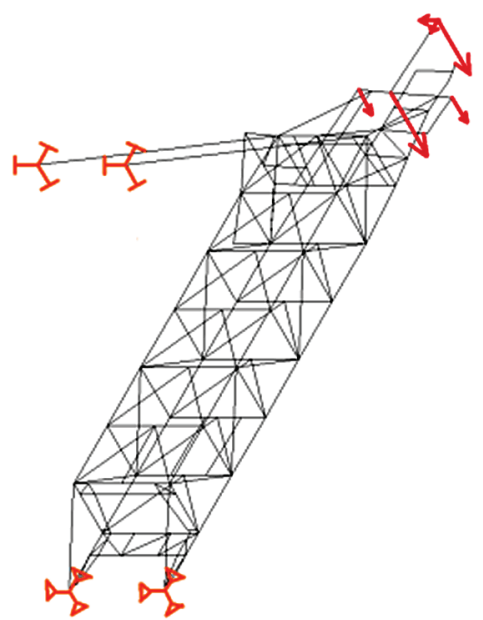

Figure 9 Dynamic model of excavator boom, boundary conditions and loads

Fig. 10 provides the appearance of elastic structure outline exposed to fictional workload for the existing boom.
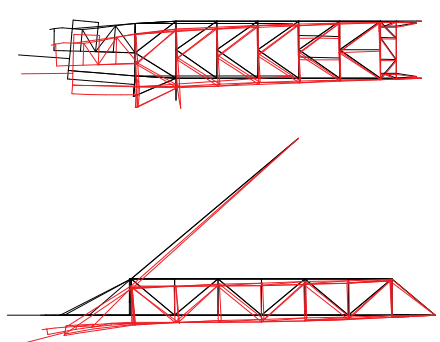

Figure 10 Displacement outline, original boom 
The excavator boom acts as a beam with overhang (fictional mobile support is on the left end where the boom is connected to the stays). Workload is a force at the end of overhang, and the whole beam is continuously loaded by its own weight (dead load).

Displacement outline for the boom extended for 2,6 and $9 \mathrm{~m}$ can be seen in Fig. 11.

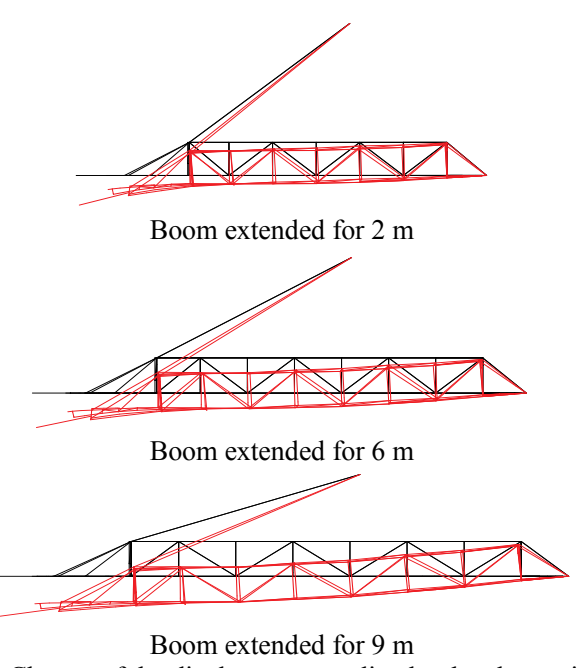

Figure 11 Change of the displacement outline by the change in length, static calculation

It can be seen that for a small extension the boom remains rigid, while for a large one it becomes elastic.

Tab. 3 and Fig. 12 show the total deflection and deflection change for all steps of the boom extension.

Table 3 Deflection change by the boom extension

\begin{tabular}{|c|c|c|}
\hline $\begin{array}{c}\text { Boom extension } \\
(\mathrm{m})\end{array}$ & Deflection $(\mathrm{mm})$ & $\begin{array}{c}\text { Deflection } \\
\text { increasing }(\%)\end{array}$ \\
\hline 0 & 44,97 & 0 \\
\hline 1 & 46,20 & 2,74 \\
\hline 2 & 47,66 & 5,98 \\
\hline 3 & 49,73 & 10,58 \\
\hline 4 & 51,92 & 15,45 \\
\hline 5 & 54,73 & 21,70 \\
\hline 6 & 57,54 & 27,95 \\
\hline 7 & 62,32 & 38,58 \\
\hline 8 & 70,55 & 56,88 \\
\hline 9 & 84,32 & 87,50 \\
\hline 10 & 125 & 177,96 \\
\hline
\end{tabular}

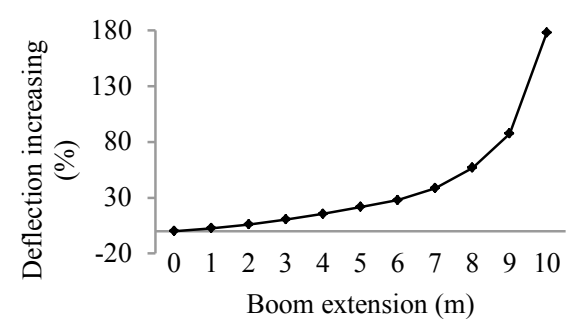

Figure 12 Deflection increasing by the boom extension

It can be seen that starting from $6 \mathrm{~m}$ onwards deflection increases exponentially with increasing the boom length.

The change of equivalent stress in an element of the lower band of the first segment (near boom bearing), which indicates respectively a high level of stress in the case of basic and extended booms, is provided in Tab. 4 and Fig. 13.

Table 4 Change of equivalent stress in one element of the lower band that indicates a high level of stress as in the case of original boom and

\begin{tabular}{|c|c|c|}
\hline \multicolumn{3}{|c|}{ in cases of extended booms } \\
\hline $\begin{array}{c}\text { Boom extension } \\
(\mathrm{m})\end{array}$ & $\begin{array}{c}\text { Equivalent stress } \\
(\mathrm{MPa})\end{array}$ & $\begin{array}{c}\text { Stress increasing } \\
(\%)\end{array}$ \\
\hline 0 & 56,47 & 0 \\
\hline 1 & 58,57 & 3,72 \\
\hline 2 & 61,19 & 8,36 \\
\hline 3 & 65,08 & 15,25 \\
\hline 4 & 68,71 & 21,68 \\
\hline 5 & 73,20 & 29,63 \\
\hline 6 & 77,59 & 37,40 \\
\hline 7 & 83,37 & 47,64 \\
\hline 8 & 92,88 & 64,48 \\
\hline 9 & 104,20 & 84,52 \\
\hline 10 & 132,90 & 135,35 \\
\hline
\end{tabular}

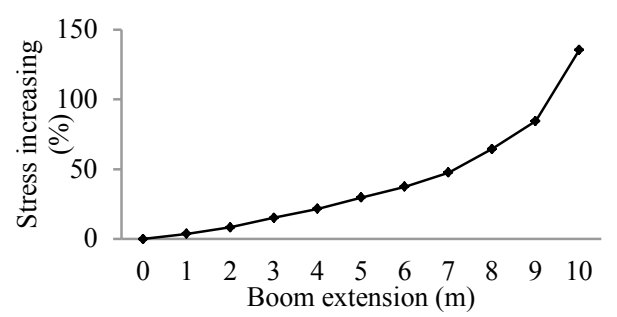

Figure 13 Equivalent stresses increasing by the boom extension

It may be noted that by the boom extension of $6 \mathrm{~m}$ stress in this element is increased by more than $30 \%$ of the stress value in the same element of the existing excavator boom.

In addition, it can also be noted that a large extensions of the boom $(8,9$ and $10 \mathrm{~m})$ are not technically acceptable.

\section{Conclusion}

Bucket-wheel excavators are complex systems with a large number of functionally important elements. In order to find out a valid criterion for defining the structure elements and also for the assessment of technical conditions, extensive diagnostic tests are necessary. The first step is modelling the structure with derived optimizations.

Bucket wheel boom can be classified as a very responsible construction, because failures of certain elements on the bucket wheel boom can lead to a breakdown condition of the BWE.

Conclusions and recommendations based on all the foregoing is that without changing of the truss structure (height and width of truss, grid and cross-sections of beams), maximum boom extension of $5 \mathrm{~m}$ can be made.

\section{Acknowledgements}

This article is a contribution to the Ministry of Education, Science and Technological Development of Republic of Serbia funded projects TR35040. Note: This paper is based on the paper awarded as the best $\mathrm{PhD}$ student paper at the $7^{\text {th }}$ International Conference TEAM 2015 [12]. 


\section{$7 \quad$ References}

[1] Vladić, J.; Đokić, R.; Kljajin, M.; Karakašić M. Modelling and Simulations of Elevator Dynamic Behavior. // Tehnicki vjesnik - Technical Gazette. 18, 3(2011), pp. 423-434.

[2] Rusinski, E.; Harnatkiewicz, P.; Kowalczyk, M.; Moczko, P. Examination of the causes of a bucket wheel fracture in a bucket wheel excavator. // Journal of Engineering Failure Analysis. 17, 6(2010), pp. 1300-1312. DOl: 10.1016/j.engfailanal.2010.03.004

[3] Bošnjak, S.; Petkovic, Z.; Zrnic, N.; Simic, G.; Simonovic, A. Cracks, repair and reconstruction of bucket wheel excavator slewing platform. // Journal of Engineering Failure Analysis. 16, 5(2009), pp. 1631-1642. DOl: 10.1016/j.engfailanal.2008.11.009

[4] Jovančić, P.; Tanasijević, M.; Ignjatović, D. Relation between numerical model and vibration: behavior diagnosis for bucket wheel drive assembly at the bucket wheel excavator. // Journal of Vibroengineering. 12, 4(2010), pp. 500-513.

[5] Jovančić, P.; Ignjatović, D.; Tanasijević, M.; Maneski, T. Load-bearing steel structure diagnostics on bucket wheel excavator, for the purpose of failure prevention. // Journal of Engineering Failure Analysis. 18 (2011), pp. 12031211. DOI: 10.1016/j.engfailanal.2011.03.001

[6] Brkić, A. D.; Maneski, T.; Ignjatović, D.; Jovančić, P.; Spasojević Brkić, V. K. Diagnostics of bucket wheel excavator discharge boom dynamic performance and its reconstruction. // Eksploatacja i niezawodnosc - Journal of Maintenance and Reliability. 16, 2(2014), pp. 188-197.

[7] Bošković, S.; Jovančić, P.; Ignjatović, D.; Rakićević, B.; Maneski, T. Vibration as deciding parameter during revitalization process for replacing the bucket wheel drive. // Journal of Vibroengineering. 17, 1(2015), pp. 24-32.

[8] Ignjatović D.; Petrović B.; Jovančić P.; Bošković S. Impact of the Bucket Wheel Support at Technical Parameters of the Block and Bucket Wheel Excavator Capacity. // Proceedings of the $12^{\text {th }}$ international symposium continuous surface mining / Aachen 2014, pp. 73-81.

[9] Maneski, T.; Milošević-Mitić, V. Numerical and experimental diagnostic of structural strength. // Structural integrity and life. 10, 1(2010), pp. 3-10.

[10] Trišović, N.; Maneski, T.; Kozak, D. Developed procedure for dynamic reanalysis of structures. // Strojarstvo Journal for Theory and Application in Mechanical Engineering. 52, 2(2010), pp. 147-158.

[11] Maneski, T.Computer Modeling and Calculation of Structures, Faculty of Mechanical Engineering, Belgrade, 1998. (in Serbian).

[12] Petrović, B.; Petrović, A.; Ignjatović, D.; Grozdanović I. Dynamic behaviour and stress field of excavator SchRs 740 extended boom. // Proceedings of $7^{\text {th }}$ International Conference TEAM 2015, pp. 345-348.

\section{Authors' addresses}

M. Sc. Branko Petrović, Ph.D. student Mining Basin Kolubara, Kolubara Project, Svetog Save 1, 11550 Lazarevac, Serbia E-mail: branko.petrovic@rbkolubara.rs

M. Sc. Ana Petrović, Teaching Assistant

University of Belgrade,

Faculty of Mechanical Engineering,

Kraljice Marije 16, 11000 Belgrade, Serbia

E-mail: aspetrovic@mas.bg.ac.rs

Dr.sc. Dragan Ignjatović, Full Professor

University of Belgrade,

Faculty of Mining and Geology,

Đušina 7, 11000 Belgrade, Serbia

E-mail: dragan.ignjatovic@rgf.bg.ac.rs

Dr.sc. Ines Grozdanović, Associate Professor

University of Belgrade

Faculty of Mining and Geology

Đušina 7, 11000 Belgrade, Serbia

E-mail: ines.grozdanovic@rgf.bg.ac.rs

\section{Dr.sc. Dražan Kozak, Full Professor}

Josip Juraj Strossmayer University of Osijek,

Mechanical Engineering Faculty in Slavonski Brod,

Trg Ivane Brlić Mažuranić 2, 35000 Slavonski Brod, Croatia

E-mail:dkozak@sfsb.hr

Dr.sc. Marko Katinić, Lecture

College of Slavonski Brod, Technical Department, Dr. Mile Budaka 1, 35000 Slavonski Brod, Croatia E-mail: marko.katinic@vusb.hr 